\author{
К ВОПРОСУ ОБ ЭТНОКУЛЬТУРНОЙ СПЕЦИФИКЕ \\ РУССКИХ ПРОИЗВОДНЫХ С ФОРМАНТОМ -УШК- / -ЮШК- \\ И ИХ СООТВЕТСТВИЯХ В НЕМЕЦКОМ ЯЗЫКЕ \\ В СВЕТЕ КОГНИТИВНО-ДИСКУРСИВНОГО АНАЛИЗА
}

(C) Ирина Абдулганеева

\section{ON THE LINGUOCULTURAL SPECIFICITY OF RUSSIAN NOMINAL DERIVATIVES WITH THE FORMANT -USHK/-YUSHK AND THEIR EQUIVALENTS IN GERMAN: A COGNITIVE DISCURSIVE ANALYSIS}

\begin{abstract}
Irina Abdulganeeva
This article presents the results of a comparative typological study of the ethnocultural specificity of the Russian and German word-forming units in the light of the cognitive-discourse paradigm in current linguistic research. Based on the analysis of the word-formation model with the formant -usk/-yushk, namely, the derivatives with the formants -usk/-yushk in Russian and their translated equivalents in German, the study reveals the cognitive-mental nature of the actualization of the functional-semantic potential of derivatives with the formant -usk /-yushk in different types of Russian-language discourse in conceptualization of the external and internal world of native speakers and the resulting features of these units translated into German. The word-formation formant -ushk- / -yushk- is productive in relation to lexical units, whose denotative meaning is concepts in the Russian picture of the world. Functioning as important concepts of Russian linguoculture, neutral substantives fate, field, mother, will, etc. are actualized in the language in the form of derivatives with the formant -ushk- / -yushk-. The word-formation model with -usk/-yushk is productive in relation to Russian proper names or vocatives. The largest number of examples with proper names is found in the NKRYA, these proper names represent ethnocultural specifics and are used by native speakers of the Russian language in various types of discourse.
\end{abstract}

Keywords: ethnocultural semantics, derivatives, word-formation model, cognitive-discursive analysis, comparative-typological research.

В статье представлены результаты сопоставительно-типологического исследования этнокультурной специфики словообразовательных единиц русского и немецкого языков в свете когнитивно-дискурсивной парадигмы современных лингвистических исследований. На материале анализа словообразовательной модели с формантом -ушк- / -юшк-, а именно производных с формантом ушк- / -юшк- в русском языке и их переводных соответствий в немецком языке, обоснованы когнитивно-ментальная природа актуализации функционально-семантического потенциала производных с указанным формантом в разных видах русскоязычного дискурса в процессе концептуализации внешнего и внутреннего мира носителей языка и возникающие в связи с этим особенности передачи данных единиц на немецкий язык. Словообразовательный формант -ушк- /-юшкпродуктивен в отношении лексических единиц, денотативное значение которых для русской картины мира представляет собой концепты. Функционируя в качестве важных концептов русской лингвокультуры, нейтральные субстантивы судьба, поле, мать, воля и др. актуализируются в языке в форме производных с формантом -ушк-/ -юшк-. Словообразовательная модель с -ушк- / -юшкоказывается продуктивной в отношении русских имен собственных или вокативов. Наибольшее количество примеров в отношении имен собственных демонстрирует и НКРЯ, имена собственные репрезентируют этнокультурную специфику и используются носителями русского языка в различных видах дискурса.

Ключевые слова: этнокультурная семантика, производные, словообразовательная модель, когнитивно-дискурсивный анализ, сопоставительно-типологическое исследование. 
Язык каждого народа или этнической группы представлен набором национально-специфических маркеров, которые выделяют данный язык среди всех других. Отражение национальной картины мира и его концептуализация посредством народно-этнического и авторского литературного творчества - неотъемлемая часть духовно-нравственного наследия каждого народа. Концептуализация сознания осуществляется разноуровневыми средствами определенной лингвокультуры. Сегодня особенно активно ученымилингвистами изучаются семантические аспекты словообразовательных феноменов, участвующих в категоризации и концептуализации внешнего и внутреннего мира человека.

Сопоставительно-типологические исследования в свете когнитивно-дискурсивной парадигмы современных лингвистических исследований позволяют выявить общие и специфичные семантические и структурные аспекты словообразовательных единиц, репрезентирующих в том или ином виде дискурса национально-коннотативный компонент, отмеченные этнокультурной спецификой.

Настоящая работа ставит своей целью исследовать и обосновать этнокультурную специфику русского языка в сопоставлении с немецким языком на основе изучения словообразовательного уровня русского языка, а именно рассмотрения функционально-семантических особенностей производных, образованных формантом -ушк- / -юшк-, и способов их передачи на немецкий язык. Анализу подвергнуты словообразовательные модели с вышеуказанным формантом и их соответствия в немецком языке.

Актуальность настоящего исследования продиктована необходимостью рассмотрения и углубленного изучения возможностей словообразовательного уровня языка в процессе концептуализации явлений и процессов окружающей действительности, миропонимания; необходимостью обоснования когнитивно-ментальной природы словообразовательных процессов.

Очевидно, что представления, которые образуют языковую картину мира, присутствуют в значении слов, выражений и конструкций языка в имплицитной форме - в идее презумпций, коннотаций, условий осмысленности, фоновых знаний и других типов имплицитных компонентов, содержащихся в языковых единицах [Зализняк, 2013, с. 273]. Данный потенциал языковые единицы актуализируют в определенном тексте, именно текст и его содержание порождают спектр эксплицитно и имплицитно выраженных значений языковых единиц. На наш взгляд, спра- ведливым представляется указание В. Н. Комиссарова на то, что содержание текста определяется не только набором и организацией составляющих его единиц, но и когнитивными знаниями участников общения, а также той ситуацией, в которую включается текст в акте коммуникации, и той иллокутивной функцией, которую текст выполняет [Комиссаров, с. 11].

В трудах ученых Казанской лингвистической школы (И. А. Бодуэна де Куртенэ, Н. В. Крушевского, В. А. Богородицкого, А. И. Анастасиева, а также ее современных представителей Г. А. Николаева, Э. А. Балалыкиной и др.) отмечалась и отмечается необходимость анализа и изучения семантического аспекта словообразования: «Словообразование теснейшим образом связано с семантикой, стилистикой и другими разделами языковой реальности. Семантические основания, заложенные в праславянском языке в определенные словообразовательные типы, по-разному реализуются в отдельных славянских языках, что связано в первую очередь с экстралингвистикой (жизненным опытом носителей конкретного славянского языка, их мировосприятием, культурными реалиями и т. д.» [Николаев, с. 58].

Идиоэтническая специфика прослеживается, прежде всего, на лексико-семантическом уровне языка: она сказывается на способах мотивации и на распределении объема значений слова (общепринятых его осмыслений, или так называемых «словарных значений»). Индивидуальные особенности отдельно взятого исторического языка проявляются прежде всего в уникальности смысловых образований (и соответствующих им словообразовательных типов, грамматических категорий, синтаксических конфигураций), когда речь идет о характере соотнесенности конкретных высказываний с определенными «словарными словами» и стоящими за ними предметами (предметами мысли) [Сухачев, с.88].

Практическим материалом нашего исследования послужили данные Национального корпуса русского языка (далее - НКРЯ), а также единицы, извлеченные методом сплошной выборки на основе обширного языкового материала, включая художественные произведения, которые не представлены в НКРЯ. Также анализу подверглись материалы, накопленные в ходе наблюдения и фиксирования за носителями языка во время коммуникативных ситуаций разговорного дискурса.

Для сравнительно-типологического изучения словообразовательных формантов, как и для всякого другого типологического исследования, определен набор констант, критериев, на основе 
которых будут сопоставляться языки на данном уровне. Такими константами являются для русского языка: 1) производные с формантом -ушк- / -юшк-; 2) функционально-семантический потенциал производных с формантом -ушк /-юшк- рассматривается в различных видах дискурса.

Таким образом, для сопоставительного описания суффиксальной системы русского и немецкого языков выделены словообразовательные схемы и модели в исследуемых языках.

Среди различных языковых средств, которые служат языковой репрезентации эмоциональночувственного мира человека и направлены на повышение экспрессивности и субъективнооценочного выражения смыслового полотна текста, немецкий лингвист S. Ullmann в числе первых называет «эмоциональные» производные („Emotionale Ableitungen“), образованные диминутивными или аугментативными суффиксами („Bestimmte Suffixe - Diminutiva, Augmentativa“). В данных производных денотативное значение корневой основы слова сопровождается коннотацией или оценочностью (,...sie legen der Bedeutung des Stammwortes einen Gefühlsbeiklang oder ein Werturteil bei.") [Ullmann, c. 167]. Говоря о статусе суффикса в языке, Н. Д. Арутюнова подчеркивает, что «все суффиксы входят в арсенал технических средств словообразования и объединены общим для всех них назначением создания в языке новых слов. Это качество и отличает их от элементов формообразования. Однако в указанных пределах вскрывается сложный и запутанный механизм взаимодействия суффикса и производящей основы, наблюдаются самые различные случаи вхождения суффикса в словопроизводство, свидетельствующие о неоднородности функций, обслуживаемых суффиксами» [Арутюнова, с. 273]. Г. О. Винокур полагал, что «аффикс может иметь какой-нибудь смысл только тогда, когда он применен к какой-нибудь основе, а не существует сам по себе» [Винокур, с. 426]. Правильнее было бы говорить не о значении отдельного аффикса, а о значении, которое создается совокупностью всех структурных компонентов производного слова, иначе говоря, о значении образца [Улуханов, с. 102].

Многие ученые отмечают стилистический потенциал словообразовательных ресурсов словообразовательной системы русского языка: «...сердцевину стилистических ресурсов в словообразовании составляют суффиксы и префиксы субъективной оценки» [Кожина, с. 242]. Данный факт продиктован флективным характером русского языка, в русском языке развита деривационная система, отмеченная наличием большого количества суффиксов, выражающих субъек- тивно-оценочное значение. Для деривационной системы немецкого языка характерно словосложение. Как семантика русских дериватов, образованных посредством суффиксальных формантов, так и семантические неопределенности сложносоставных слов немецкого языка вызывают у лингвистов многочисленные вопросы. Основанием для неясного и неопределенного характера в вопросе о словообразовательной семантике выступают многочисленные случаи, в которых сложносоставные слова проявляют значение непредсказуемое или стохастическое (,еіne unvorhersagbare Bedeutung"). Эти слова, таким образом, скрывают семантические образцы (,sеmantische Muster"), которые ранее не были актуализированы [Ullmann, c. 396].

Исследуемая нами словообразовательная модель активно функционирует во всех типах дискурса: художественном, разговорно-бытовом, песенном, сказочном, газетно-журнальном и т. д. Методом сплошной выборки нами было извлечено из различных источников и проанализировано свыше 1000 дериватов с формантами -ушк- / -юшк-. Более того, следует отметить, что производные с указанными формантами, которые начали активно использоваться русскими классиками 18-19 столетий Ф. М. Достоевским, Л. Н. Толстым, И. С. Куприным и др., активно функционируют и в произведениях современных авторов. Данные НКРЯ демонстрируют контексты с производными с -ушк- / -юшк- различных видов дискурса: (1) Суффикс «ушк-юшк», объясняла я иностранцам, которых учила русскому языку, обозначает старинную задушевную интонацию по отношению к явлению, предмету или человеку - матушка, волюшка, полюшко, соловушка (Алексей Слаповский. 100 лет спустя. Письма нерожденному сыну // «Волга», 2009) [НКРЯ] (здесь и далее разрядка наша - И. А.); (2) Не по морюшку... и лебедушка пльвет, Выше бережка головушку несет, Не ко мне ли родна матушка идет (М. М. Пришвин. Дневники (1923) [Там же]; (3) Да по ветру прямо на меня идет! Эх, судьбинушка неласковая! Готовился помереть, а как вышла смерть навстречу, оробел... (Вадим Бурлак. Хранители древних тайн (2001)) [Там же] (здесь и далее курсив наш - И.А.).

Устное народное творчество, представленное былинами, песнями, сказаниями и сказками, также изобилует производными с формантом -ушк- /-юшк-:

(4)Полюшко-поле,

Полюшко, широко поле.

Едут по полю герои,

Эх, да Красной Армии герои! [Гусев] 
Сказки, как вид народного творчества, входят составной частью в так называемую народную прозу. Кроме сказок, к народной прозе относятся предания, былины, легенды и сказы. Эта несказочная проза отличается от сказок прежде всего тем, что в то, о чем она повествует, люди верили. Образования с формантом -ушк- /-юшк- встречаются уже в названиях сказок: Лисушкина свадьба [Сказки, с. 538] с.538, Снегурушка и лиса [Там же, с. 539], Козел и козлушка [Там же, с. 540], Курочка Татарушка [Там же, с. 540], ДарьюшкаЗамазурка [Там же, с. 541], Горюшко [Там же, с. 541], Сестрица Аленушка и братец Иванушка [Там же, с. 542].

Около двадцати процентов от общего числа анализируемых единиц, которые мы зафиксировали из обширного песенного и стихотворного материла методом сплошной выборки, функционируют в песенном и поэтическом дискурсе современных авторов. При выражении мыслей о родном крае, о Родине представителям русской языковой картины мира сознание напоминает строки известных русских песен, стихов, отрывков из произведений русских классиков, наполненных такими единицами, как судьбинушка, полюшко, матушка, волюшка. Функционируя в качестве важных концептов русской лингвокультуры, нейтральные субстантивы судьба, поле, мать, воля актуализируются в языке именно в форме производных с формантом -ушк- / -юшк-:

(5) Не гони лошадей ты, Судьбинушка!

Дай мне вдоволь испить Жизнь свою...

Ох, и больно хлестала ты спинушку.

Но я жив! И еще песнь спою! [Крайнов]

(6) Доля ты моя, доля-долюшка.

Да судьбинушка моя, непонятная.

От чего ты не со мною, моя Олюшка?

Ой, красавица моя, ненаглядная.

Доля ты моя доля-долюшка.

Да судьбинушка моя, непонятная.

От чего ты не со мною, моя зорюшка?

Ой, красавица моя, ненаглядная [Зацепин].

Словообразовательная модель с -ушк- /-юшкоказывается продуктивной в отношении русских имен собственных или вокативов. Наибольшее количество примеров в отношении имен собственных демонстрирует и НКРЯ. Рассмотрим данное положение на примере имени собственного Анна и его формы с формантом -ушк- - Aннушка. В соответстви со сферой функционирования зафиксированы следующие показатели для формы Аннушка: художественная - 210 документов с числом вхождений 1474 (86.00\%), публицистика - 79 документов с числом вхождений
152 (8.87\%), бытовая - 19 документов с числом вхождений 66 (3.85\%), учебно-научная - 7 документов с числом вхождений 12 (0.70\%), электронная коммуникация - 3 документа с числом вхождений 6 (0.35\%), художественная проза - 1 документ с числом вхождений 4 (0.23\%), церковно-богословская - 1 документ с числом вхождений $1(0.06 \%)$ [НКРЯ].

Основополагающим положением при анализе имен собственных для нас явилось то, что «...во всех сферах духовной жизни человека - религиозной, провиденциально-профетической, спекулятивно-философской, художественно-эстетической, социально-общественной - роль имени не только велика, но по особому отмечена, и то, что поддается учету и пересказу, образует лишь поверхностный слой той тайны, которая связана с именем. Но даже прикосновение к этому слою намекает и на глубину этой тайны, и на ту силу, которая от нее неотделима» [Топоров, с. 380].

Имя, по нашему убеждению, является одним из ключевых репрезентантов этнокультурной специфики языка, в связи с чем требует детального подхода при поиске соответствия при переводе на иностранный язык. Особенную сложность для переводчиков представляют ласкательные и уменьшительно-ласкательные формы русских имен, которые традиционно образовывались посредством форманта -ушк- / -юшк-. Данные формы продуктивны и активно использовались и используются носителями русского языка в различных видах дискурса: былинном Добрынюшка, сказочном - Иванушка, Аленушка, Марьюшка, разговорном - Левушка (от имени Лев), Глебушка (от имени Глеб). Более того, многие формы - Аннушка, Олюшка, Иванушка и т. д. - узнаваемы и для иноязычного реципиента благодаря художественным произведениям таких всемирно известных русских писателей, как Л. Н. Толстой, Ф. М. Достоевский, М. Шолохов, В. Шукшин и др.

В НКРЯ представлено 55 вхождений имени Аннушка, лишь в одном случае переводчик переводит анализируемую единицу посредством диминутивного суффикса -chen: (7) Она доверчиво, ясно и чисто взглянула в глаза. - Вы огорчены сегодня, Петер? - Аннушка, ты меня любишь? На это Анна только быстро опустила голову, на шее ее была повязана бархатка (А. Н. Толстой. Петр Первый (1929-1943)). - Vertrauensvoll sah sie ihm mit klarem und hellem Blick in die Augen: „Sie sind heute betrübt, Peter?" „Annchen, liebst du mich?" Bei diesen Worten senkte Anna nur rasch den Kopf, ein Sammetbändchen schmückte ihren Hals... (Alexei Tolstoi. Peter der Erste (Maximilian Schick, 1944)) [НКРЯ]. 
Во всех остальных случаях при передаче имени используется транслитерация. Такой способ передачи наблюдается и в отношении французского и английского языков: (8) - Aннуш $\kappa a$, милая, что мне делать? - рыдая, проговорила Анна, беспомощно опускаясь на кресло (Л. Н. Толстой. Анна Каренина (ч. 5-8) (1873-1877)) - «Annuschka, liebe Annuschka, was soll ich tun?» sagte Anna schluchzend und ließ sich hilflos auf einen Sessel sinken (Lew Tolstoi. Anna Karenina (5.-8. Teile)) [НКРЯ].

Анализируемая словообразовательная модель демонстрирует свою продуктивность также в отношении наименований лиц, обозначающих обращения (например, Солдатушка), и обращений по степени родства (например, дядюшка, тетушка, братушка, матушка, женушка). Если смотреть на родовую принадлежность мотивирующего слова, то следует отметить, что формант -ушк- / -юшк- соотносится со всеми родами: мужской род (дядя, брат, солдат и т. д.), женский род (тетя, мама, жена), средний род (поле - полюшко, горе - горюшко, море - морюшко и m. д.). Существительные с безударным суффиксом -ушк- имеют ласкательное значение. Родовая характеристика мотивирующего слова сохраняется; при этом существительные женского рода и одушевленные мужского рода относятся ко второму склонению (флексия -а в им. п. ед. ч.), а существительные сред. р. и неодушевленные муж. p. - к первому склонению (флексия -о): а) сторонушка, головушка, коровушка, зимушка, долюшка, вдовушка, нянюшка, кумушка (жен.р), сиротинушка (общ.р.), братушка, соседушка, детинушка, дядюшка, тестюшка, соловушка (муж. р., одушевл.) [Русская грамматика, 1980, с. 213].

Примером деэтимологизации для немецкого языка является обращение das Mädchen - девуш$\kappa a$, das Märchen - сказка. Утрата соотнесенности с мотивирующей основой влечет к нерасчленимости основы и форманта -chen. В процессе развития языка меняются не только словообразовательные структуры слов, слова могут утрачивать родственные отношения, вычленяемые прежде морфемы перестают выделяться [Сорокина, с. 90].

Русское слово девушка сегодня также не воспринимается как ласкательное или эмоционально-окрашенное, формант -ушк- актуализирует только словообразовательное значение и указывает на то, что это существительное женского рода первого склонения.

Практика исследования показывает, что в разных лексикографических источниках часто приводятся различные дефиниции значений од- них и тех же слов. Это значит, что содержание концепта и его актуализация в языке неисчислимы. Каждое слово репрезентирует в определенном контексте лишь часть концептуальных характеристик, значимых для определенной коммуникации. Это же утверждение Н. Н. Болдырева правомерно применить и в отношении производных имен, их функционально-семантический потенциал актуализируется в определенном виде дискурса и конкретной коммуникативной ситуации. В то же время за счет этих характеристик слово включает данный концепт в мыслительную деятельность, обеспечивает к нему доступ, в результате чего могут быть активизированы и другие концептуальные характеристики (скрытые, вероятностные, ассоциативные - то, что получило название инференции, выводного знания) [Болдырев, с.26].

Примеры дериватов с формантом -ушк- / -юшк-, функционирующие в художественном дискурсе, например, в произведениях русской классической литературы, показывают частотность применения при переводе на немецкий язык словообразовательной модели с диминутивным суффиксом -chen (Mütterchen, Onkelchen, Brüderchen). Рассмотрим данное утверждение на примере деривата матушка. В НКРЯ зафиксировано 793 вхождения словоформы матушка. Частотным переводным соответствием русского деривата матушка является в немецком языке словоформа Mütterchen, данное соответствие мы относим к словообразовательному уровню, так как дериват образован посредством диминутивного форманта -chen и также выражает ласкательное значение. Транслитерированное переводное соответствие Matuschka используется в случае словообразовательной омонимии. В приведенном примере речь идет об омоморфемах: матушка суффикс -ушк- актуализирует ласковое обращение к матери, Матушка Великая - суффикс -ушкактуализирует словообразовательное значение, обозначающее духовный сан или религиозный статус, отмечается также графическим маркером, а именно написанием с заглавной буквы: (9) $A$ Матушка Великая, как любовно называли преподобную Анастасию ее сестры-инокини, была с нами своим ласковым взором с иконы, подаренной приходу нашим владыкой Марком (Вестник Германской епархии РПЦЗ, № 1, 2011) - Die Große Matuschka aber, wie die heilige Anastasia liebevoll von ihren Nonnenschwestern genannt wurde, war mit uns durch den zärtlichen Blick ihrer Ikone, welche der Gemeinde von unserem Vladyka Mark geschenkt wurde. (Der Bote, No. 1 (2011) [НКРЯ]. Вторую группу по частотности переводных соответствий деривата матушка зани- 
мают нейтральные лексические единицы немецкого языка Mutter, Mama, Mammam. Данные соответствия передают только денотативное значение и не выражают ласкательного или уменьшительно-ласкательного значения. Третью группу составляют местоименные замены и лексические замены деривата матушка, например: sie - в переводе с немецкого 'она'; Frau - в переводе с немецкого 'женшчина'; die Alte - в переводе с немецкого 'пожилая женщина'. Анализ немецких переводных соответствий русских производных с формантом -ушк- / -юшк- указывает на следующие тенденции в элиминировании: 1) переводные соответствия, образованные при помощи диминутивных суффиксов немецкого языка: в этом случае речь идет о возможности сохранения субъективно-оценочного значения, мелиоративной или пейоративной оценки, выражаемой в определенных дискурсивноконтекстных условиях производным с формантом -ушк/-юшк-; 2) переводные соответствия лексического уровня: используются лексические единицы, которые передают только денотативное значение оригинала, элиминирование субъективно-оценочного значения отсутствует; 3 ) переводные соответствия, сочетающие лексические и словообразовательные средства при переводе [Абдулганеева, с.13-14].

Следующую группу составляют междометия, отрицательные частицы, а также слова, выражающие согласие. В разговорном дискурсе «нейтральные» варианты носителями русского языка используются в формах с формантом -ушк- / -юшк-. В ходе наблюдений за речью русскоязычных носителей зафиксированы следующие случаи употребления: (10) - Валюха, ну иди скорее сюда! - Аю ики, бегу! (от междометия $A \check{u})$; (11) -Нетушки, не поеду я! (от отрицательного слова нет); (12) -В о туш ки тебе на! А заранее сказать не мог?! (от частицы вот для выражения удивления). Важными для исследования когнитивно-ментальной природы словообразовательных формантов является их рассмотрение на примере иноязычных слов, носители языка удивительно просто моделируют различные образования с суффиксом -ушк-/-юшк-, используя, например, заимствования из английского, немецкого языков: (13) Оке ю ики, сама все сделаю! (от англицизма ок, выражает согласие); (14) Г а с ар байтушки в пути, без них стройка остановилась! (от немецкого заимствования гастарбайтер, в приведенном примере формант -ушк- / актуализирует одобрение по отношению к иностранным рабочим). Система языка - это динамичная система, постоянное изменение и допущение чужеродных элементов заложены в самом характере системы [Толковый словарь конца XX века. Языковые изменения, с.7].

Иноязычные слова становятся в различных видах дискурса «своими» для носителя посредством использования русских формантов. Данные образования активно функционируют в разговорном дискурсе, являются эмоционально окрашенными и подчеркивают экспрессивный характер высказывания. Анализ словообразовательной модели производных с формантом -ушк/ -юшк- подтверждает наше положение об этнокультурной специфике этого форманта, так как он репрезентирует представления русскоязычного носителя на когнитивно-ментальном уровне, «...речь идет о каких-то представлениях о мире, свойственных носителям русского языка и русской культуры и воспринимаемых ими как нечто самоочевидное. Эти представления находят отражения в семантике языковых единиц, так что, овладевая языком, и в частности значением слов, носитель языка одновременно сживается с этими представлениями, а будучи свойственными (или хотя бы привычными) всем носителям языка, они оказываются определяющими для ряда особенностей культуры, пользующейся этим языком» [Зализняк, Левонтина, Шмелев, с.143].

Помимо функционально-семантического потенциала форманта -ушк- / -юшк-, следует отметить способность форманта присоединяться к различным мотивированным основам, что свидетельствует о том, что модель продуктивна не только в отношении производных женского и мужского рода, но и при образовании ласкательных форма мужских и женских имен собственных, использовании эмоционально-окрашенных междометий (Нетушки, Океюшки и т. д.) При установлении отношений производности надлежит руководствоваться не столько соображениями морфологического порядка о возможности или невозможности членения слова на этом уровне, сколько данными, релевантными (имеющими определяющее значение) на уровне словообразования - данными о структурносемантических особенностях анализируемого образования. Последние касаются, в частности, и его места среди других однокорневых или одноструктурных образований [Кубрякова, с.33]. Существенным остается вопрос о продуктивности суффикса -ушк- / -юшк- в отношении образований, производящей основой которых выступают числительные. Согласно выдающемуся ученому Казанской лингвистической школы Э. А. Балалыкиной, «грамматическая категория числа один из важнейших ,Полигонов“ конфликта смысла и грамматики. На фоне регулярно образуемых и противопоставленных по семантиче- 
скому признаку имен, обозначающих единичность или множественность называемых предметов, существует достаточно большое количество различных отклонений от указанной системы, когда семантика слова препятствует образованию той или иной формы» [Балалыкина, с.131]. Когнитивно-дискурсивный анализ производных с формантом -ушк- / -юшк- вносит дополнение относительно того, что функционирование формы множественного или единственного числа таких производных может быть обусловлено видом дискурса. Так, например, такие единицы как однокомнатная квартира или двухкомнатная квартира сегодня функционируют в форме образований с -ушк-: однушка, двушка. Однушка, как правило, квартира малых размеров (от 20 кв. м), квартира-студия, которая совмещает гостиную, спальню и кухню. Функционирование единственного числа однушка, двушка зафиксировано как в разговорном, так и в рекламном дискурсе: (15) Игорек наш, уже и однушку успел купить! Двушку же хотел, поди не хватило!? (из беседы пассажиров автобуса).

В текстах рекламного дискурса, основной целью которых является также привлечение потенциальных покупателей одно- и двухкомнатных квартир, наблюдается высокая частотность употребления однушки и двушки: (16) «Хит продаж! Классическая однушка с раздельным с / у от 1778000 руб» [Хит продаж]; (17) Полноценная однушка с гардеробной [Полноценная однушка с гардеробной]; (18) Комфортная двушка [Комфортная двушка]. Однако формы множественного числа анализируемых единиц зафиксированы только для письменных рекламных текстов, размещенных на рекламных щитах или в различного рода рекламных объявлениях в сети Интернет: (19) Модные двушки [Модные двушки]. (20) Однушки на южную сторону от 1327000 руб. [Однушки на южную сторону]. Примеры использования множественного числа однушки, двушки на основе анализа диалогической речи персонажей текстов художественного дискурса, а также наблюдений за коммуникативными ситуациями носителей русского языка зафиксировать не удалось. Соответствиями в немецком языке для образований с -ушк- / -юшк- выступают нейтральные по значению сложносоставные образования Einzimmerwohnung - 'однокомнатная квартира', Zweizimmerwohnung - 'двухкомнатная квартира'. Данные соответствия функционируют в различных видах дискурса и могут получать эмоционально-оценочную окраску при употреблении лексических средств или построении определенного синтаксического рисунка предложения.
В отношении языковой картины мира русского человека, на наш взгляд, функционирование образований с -ушк- / -юшк- могут указывать также на социальный статус говорящего или социальный статус реципиента, которому адресован текст. При осмыслении и оценке художественного произведения, коммуникативных ситуаций разговорного и других видов дискурса и «...с точки зрения норм и правил общенародного языка и его ,живых“ ответвлений необходимо обратить внимание на то, что в способах речевого отбора и использовании разных средств общенародного языка представителями разных народных групп отражается социальная среда, разные социальные характеры». [Виноградов, с.10].

В заключение следует отметить, что словообразовательная модель с формантом -ушк- / -юшк- является продуктивной для русского языка. Производные с данным формантом в различных видах дискурса репрезентируют функционально-семантический потенциал, актуализируя национально-коннотативный компонент, отмеченный этнокультурной семантикой, которая вплетена в денотативное значение слова, чем и обусловлены трудности, возникающие при передаче производных с формантом -ушк- / -юшк- на немецкий язык.

\section{Список литературы}

Абдулганеева И. И. Способы перевода русских дериватов с суффиксами-интенсификаторами на немецкий язык // Филологические науки. Вопросы теории и практики. Тамбов: Грамота, 2012. № 7 (18): в 2х ч. Ч. I. C. $13-18$.

Арутюнова Н. Д. Проблемы морфологии и словообразования: (На материале испанского языка). М.: Языки славянских культур, 2007, 288 с.

Балалькина Э. А. Мир языка и языки мира: Избранные труды по русскому языку и балтославянским отношениям. Казань: Яз, 2012, 319 с.

Болдырев Н. Н. Когнитивная лингвистика. М.: Берлин. Директ-Медиа, 2016, 253 с.

Виноградов В. В. Язык художественного произведения // Вопросы языкознания. 1954, № 5, с. 10.

Винокур Г. О. Заметки по русскому словообразованию. «Избранные работы по русскому языку». М.: Учпедгиз, 1959, с.420.

Гусев $\quad$ B. Полюшко-поле. URL: https://ru.wikipedia.org/wiki Полюшко-поле (дата обращения: 26.06.2021)

Зализняк Анна А., Левонтина, И. Б., Шмелев, А. Д. Константы и переменные русской языковой картины мира. М.: Языки славянских культур, 2012. 696 с.

Зализняк Анна А. Русская семантика в типологической перспективе. М.: Языки славянской культуры, 2013. c. 640.

Зацепин А. Доля ты моя, доля-долюшка. URL: https://pesni.guru (дата обращения: 12.08.2021) 
Однушки на южную сторону от 1327000 руб. URL: https://yandex.ru/images/search?pos $=173 \& \mathrm{p}=5 \&$ img_url=https $\% 3 \mathrm{~A} \% 2 \mathrm{~F} \% 2 \mathrm{Fwww}$. sk-continent.ru $\% 2$ Fupload\%2Fimages\%2FAkvareli_hit_prodazh_klassiches kaya_odn._fs_(Copy).jpg\&text=однушка\%20в\%20зелен одольске\% 20 жк 20 акварель\&rpt=simage \&rlt_url=http s\%3A\%2F\%2Fim0-tub-ru.yandex.net\%2Fi\%3Fid\%3D 8de0397813082c42fb28cf329b76c777-1\%26ref\%3 Drim\%26n\%3D13\%26w\%3D999\%26h\%3D999\&ogl_url =https $\% 3 \mathrm{~A} \% 2 \mathrm{~F} \% 2 \mathrm{Fwww}$. sk-continent.ru\%2Fupload $\% 2$ Fimages\%2FAkvareli_hit_prodazh_klassicheskaya_odn._ fs_(Сopy).jpg (дата обращения: 05.07.2021)

Комфортная двушка URL: https://yandex.ru/images /search?pos=173\&p=5\&img_url=https $\% 3 \mathrm{~A} \% 2 \mathrm{~F} \% 2 \mathrm{Fww}$ w.sk-continent.ru\%2Fupload\%2Fimages\%2FAkvareli _hit_prodazh_klassicheskaya_odn._fs_(Copy).jpg\&text= однушка\% 20в\% 20зеленодольске\% 20жк\%20акварель \&rpt=simage\&rlt_url=http $\% 3 \mathrm{~A} \% 2 \mathrm{~F} \% 2 \mathrm{Fitd} 2 . \mathrm{mycdn} . \mathrm{me} \%$ 2Fimage\%3Fid\%3D896061986475\%26t\%3D20\%26plc\% 3DMOBILE\%26tkn\%3D*BvGMZ1H4TLdGENusBOPFVdmFaw\&ogl_url=https $\% 3 \mathrm{~A} \% 2 \mathrm{~F} \% 2 \mathrm{Fwww}$. skcontinent.ru\%2Fupload\%2Fimages\%2FAkvareli_hit_ prodazh_klassicheskaya_odn._fs_(Copy).jpg(дата обращения: 11.07.2021)

Кожина М. Н. Стилистика русского языка: [электронный ресурс] учебник / М. Н. Кожина, Л. Р. Дускаева, В. А. Салимовский. М.: Флинта: Наука, 2008. $464 \mathrm{c}$.

Комиссаров В. Н. Когнитивное и семантическое в тексте и проблема эквивалентности перевода. // Semantik, Kognition und Aquivalenz /hrag. Gert Jüger u. Albrecht Neubert. Leipzig.: Verlag Enzyklopädie, 1988. C.7-18

Крайнов А. Не гони лошадей ты, Судьбинушка! URL: https://www.chitalnya.ru/work/3169155/ (дата обращения: 11.07.2021)

Кубрякова E. С. Что такое словообразование. М.: Наука, 1965, 78 с.

Модные двушки URL: https://yandex.ru/images/ search?pos=173\&p=5\&img_url=https $\% 3 \mathrm{~A} \% 2 \mathrm{~F} \% 2 \mathrm{Fwww}$ .skcontinent.ru\%2Fupload\%2Fimages\%2FAkvareli_hit_p rodazh_klassicheskaya_odn._fs_(Copy).jpg\&text=однуш ка\%20в\%20зеленодольске\% 20 жк\%20акварель\&rpt=si mage\&rlt_url=https $\% 3 \mathrm{~A} \% 2 \mathrm{~F} \% 2 \mathrm{Fkovrov} . c i t y \% 2 \mathrm{Fuploads}$ \%2Fnews\%2F1_3_19_148_120002.jpg\&ogl_url=https\%3 A\%2F\%2Fwww.sk-continent.ru\%2Fupload\%2Fimages $\%$ 2FAkvareli_hit_prodazh_klassicheskaya_odn._fs_(Copy). jpg (дата обращения: 21.08.2021)

Национальный корпус русского. URL: http://www.ruscorpora (дата обращения: 10.09.2021)

Николаев Г. А. Русское и славянское языкознание. Под общ. ред. К. Р. Галиуллина; Казан. ун-т, Филол. фак. Казань: Казан. ун-т, 2011. 220 с.

Полноценная однушка с гардеробной. URL: https://yandex.ru/images/search?pos=173\&p=5\&img_url $=$ https $\% 3 \mathrm{~A} \% 2 \mathrm{~F} \% 2 \mathrm{Fwww}$. sk-continent.ru\%2Fupload $\%$ 2Fimages\%2FAkvareli_hit_prodazh_klassicheskaya_odn. _fs_(Copy).jpg\&text=однушка\%20в\%20зеленодольске $\% 20$ жк\%20акварель\&rpt=simage\&rlt_url=http\%3A\%2F \%2Fitd2.mycdn.me\%2Fimage\%3Fid\%3D901508640427 $\% 26 \mathrm{t} \% 3 \mathrm{D} 20 \% 26 \mathrm{plc} \% 3 \mathrm{DMOBILE} \% 26 \mathrm{tkn} \% 3 \mathrm{D} * \mathrm{c} \_\mathrm{AJHm}$ 3SxjqvoseUqWIkE7NJJQc\&ogl_url=https\%3A\%2F\%2F
www.sk-continent.ru\%2Fupload $\% 2$ Fimages $\%$

2FAkvareli_hit_prodazh_klassicheskaya_odn._fs_(Copy). jpg(дата обращения: 13.06.2021)

Русская грамматика. Т. 1: Фонетика. Фонология. Ударение. Интонация. Словообразование. Морфология / Н. Ю. Шведова (гл. ред.). М.: Наука, 1980. 743 с.

Сорокина Т. Н. «Совесть» или «Со +весть» // Русский язык в школе. Москва «Просвещение», №3, 1988. С.89-91.

Сказки: Кн.1 / Сост., вступ. ст., подгот. текстов и коммент. Ю. Г. Круглова. М.: Сов. Россия, 1988. 544 c.

Сухачев Н. Л. Значение и смысл слова. Лекции о лингвистическом знаке. СПб.: Нестор-История, 2019. $184 \mathrm{c}$.

Толковый словарь конца ХХ века. Языковые изменения / под. ред. Г. Н. Скляревской. СПб.: ФОЛИОПРЕСС, 1998. с.704.

Топоров В. Н. Исследования по этимологии и семантике. Т. 1: Теория и некоторые частные ее приложения. М.: Языки славянской культуры, 2005. 816 с.

Улуханов И. С. Словообразовательная семантика в русском языке и принципы ее описания. М.: Наука, 1977. 255 c.

Хит продаж! Классическая однушка с раздельным c / у от 1778000 руб. URL: https://yandex.ru/images/ search?pos $=173 \& \mathrm{p}=5 \& \mathrm{img} \_$url $=$https $\% 3 \mathrm{~A} \% 2 \mathrm{~F} \% 2 \mathrm{Fwww}$ .sk-continent.ru\%2Fupload\%2Fimages\%2FAkvareli_ hit_prodazh_klassicheskaya_odn._fs_\%28Copy\%29.jpg\& text $=\% \mathrm{D} 0 \% \mathrm{BE} \% \mathrm{D} 0 \% \mathrm{~B} 4 \% \mathrm{D} 0 \% \mathrm{BD} \% \mathrm{D} 1 \% 83 \% \mathrm{D} 1 \% 88 \%$ D0\%BA\%D0\%B0+\%D0\%B2+\%D0\%B7\%D0\%B5\%D0 $\% \mathrm{BB} \% \mathrm{D} 0 \% \mathrm{~B} 5 \% \mathrm{D} 0 \% \mathrm{BD} \% \mathrm{D} 0 \% \mathrm{BE} \% \mathrm{D} 0 \% \mathrm{~B} 4 \% \mathrm{D} 0 \% \mathrm{BE}$ $\% \mathrm{D} 0 \% \mathrm{BB} \% \mathrm{D} 1 \% 8 \mathrm{C} \% \mathrm{D} 1 \% 81 \% \mathrm{D} 0 \% \mathrm{BA} \% \mathrm{D} 0 \% \mathrm{~B} 5+\% \mathrm{D} 0$ $\% \mathrm{~B} 6 \% \mathrm{D} 0 \% \mathrm{BA}+\% \mathrm{D} 0 \% \mathrm{~B} 0 \% \mathrm{D} 0 \% \mathrm{BA} \% \mathrm{D} 0 \% \mathrm{~B} 2 \% \mathrm{D} 0 \% \mathrm{~B} 0$ $\% \mathrm{D} 1 \% 80 \% \mathrm{D} 0 \% \mathrm{~B} 5 \% \mathrm{D} 0 \% \mathrm{BB} \% \mathrm{D} 1 \% 8 \mathrm{C} \& \mathrm{rpt}=$ simage (дата обращения: 10.07.2021)

Ullmann S. Semantik. Eine Einführung in die Bedeutungslehre. Frankfurt am Main: S. Fischer Verlag, 1973. $401 \mathrm{p}$.

\section{References}

Abdulganeeva, I. I. (2012). Sposoby perevoda russkih derivatov $s$ suffiksami-intensifikatorami na nemetskii iazyk [Methods for Translating Russian Derivatives with Intensifier Suffixes into German]. Filologicheskie nauki. Voprosy teorii i praktiki. Tambov, Gramota, No. 7 (18): v 2-h ch. Ch. I, pp. 13-18. (In Russian)

Arutiunova, N. D. (2007). Problemy morfologii $i$ slovoobrazovaniia: (Na materiale ispanskogo iazyka) [Problems of Morphology and Word Formation: (Based on the Spanish Language)]. 288 p. Moscow, Iazyki slavianskih kul'tur. (In Russian)

Balalykina, E. A. (2012). Mir iazyka i iazyki mira: Izbrannye trudy po russkomu iazyku i balto-slavianskim otnosheniiam [The World of Language and the Languages of the World: Selected Works on the Russian Language and Balto-Slavic Relations]. 319 p. Kazan', Iaz. (In Russian)

Boldyrev, N. N. Kognitivnaia lingvistika. (2016) [Cognitive Linguistics]. 253 p. Moscow, Berlin. DirektMedia. (In Russian) 
Hit prodazh! Klassicheskaia odnushka s razdel'nym s/u ot 1778000 rub.[Bestseller! Classic odnushka with a separate bathroom and toilet from 1,778,000 rubles.]. URL:

https://yandex.ru/images/search?pos=173\&p=5\&img_url $=$ https $\% 3 \mathrm{~A} \% 2 \mathrm{~F} \% 2 \mathrm{Fwww}$. sk-continent.ru $\% 2 \mathrm{Fupload} \%$ 2Fimages\%2FAkvareli_hit_prodazh_klassicheskaya_odn. _fs_\%28Copy\%29.jpg\&text=\%D0\%BE\%D0\%B4\%D0\% BD\%D1\%83\%D1\%88\%D0\%BA\%D0\%B0+\%D0\%B2+ $\% \mathrm{D} 0 \% \mathrm{~B} 7 \% \mathrm{D} 0 \% \mathrm{~B} 5 \% \mathrm{D} 0 \% \mathrm{BB} \% \mathrm{D} 0 \% \mathrm{~B} 5 \% \mathrm{D} 0 \% \mathrm{BD} \% \mathrm{D} 0$ $\% \mathrm{BE} \% \mathrm{D} 0 \% \mathrm{~B} 4 \% \mathrm{D} 0 \% \mathrm{BE} \% \mathrm{D} 0 \% \mathrm{BB} \% \mathrm{D} 1 \% 8 \mathrm{C} \% \mathrm{D} 1 \% 81 \%$ D0\%BA\%D0\%B5+\%D0\%B6\%D0\%BA+\%D0\%B0\%D0 $\% \mathrm{BA} \% \mathrm{D} 0 \% \mathrm{~B} 2 \% \mathrm{D} 0 \% \mathrm{~B} 0 \% \mathrm{D} 1 \% 80 \% \mathrm{D} 0 \% \mathrm{~B} 5 \% \mathrm{D} 0 \% \mathrm{BB} \%$ D1\%8C\&rpt=simage (accessed: 10.07.2021) (In Russian)

Gusev, V. Poliushko-pole [Polyushko-Field]. URL: https://ru.wikipedia.org/wiki Poljushko-pole (accessed: 26.06.2021). (In Russian)

Kozhina, M. N. (2008). Stilistika russkogo iazyka: uchebnik [Stylistics of the Russian Language]. M. N. Kozhina, L. R. Duskaeva, V. A. Salimovskii. 464 p. Moscow, Flinta, Nauka. (In Russian)

Komfortnaia dvushka [A Comfortable Two-roomed Flat]. URL: https://yandex.ru/images/search?pos=173\&p= 5\&img_url=https $\% 3 \mathrm{~A} \% 2 \mathrm{~F} \% 2 \mathrm{Fwww}$. sk-continent.ru $\%$ 2Fupload\%2Fimages\%2FAkvareli_hit_prodazh_klassiche skaya_odn._fs_(Copy).jpg\&text=однушка\%20в\%20зеле нодольске\% 20жк\%20акварель\&rpt=simage\&rlt_url=htt p\%3A\%2F\%2Fitd2.mycdn.me\%2Fimage\%3Fid\%3D896 061986475\%26t\%3D20\%26plc\%3DMOBILE\%26tkn\%3 D*BvGMZ1H4TLdGENusBOP-FVdmFaw\&ogl_url= https\%3A\%2F\%2Fwww.sk-continent.ru\%2Fupload\% 2Fimages\%2FAkvareli_hit_prodazh_klassicheskaya_odn. _fs_(Copy).jpg (accessed: 11.07.2021). (In Russian)

Komissarov V. N. (1988). Kognitivnoe $i$ semanticheskoe $v$ tekste $i$ problema ekvivalentnosti perevoda [Cognitive and Semantic Aspects in the Text and the Problem of Translation Equivalence]. Pp. 7-18. Iz knigi: Semantik, Kognition und Aquivalenz /hrag. Gert Jüger u. Albrecht Neubert. 192 p. Leipzig. Verlag Enzyklopädie. (In German)

Krainov, A. (2021). Ne goni loshadei ty, Sud'binushka! [ Do Not Drive the Horses, Fate!]. URL: https://www.chitalnya.ru/work/3169155/ (accessed: 11.07.2021). (In Russian)

Kubriakova, E. S. (1965). Chto takoe slovoobrazovanie [What is Word Formation]. 78 p. Moscow, Nauka. (In Russian)

Modnye dvushki [Trendy Two-roomed Flats]. URL: https://yandex.ru/images/search?pos=173\&p=5\&img_url $=$ https $\% 3 \mathrm{~A} \% 2 \mathrm{~F} \% 2 \mathrm{Fwww}$. skcontinent.ru\%2Fupload $\% 2 \mathrm{Fi}$ mages\%2FAkvareli_hit_prodazh_klassicheskaya_odn.

_fs_(Copy).jpg\&text=однушка\%20в\%20зеленодольске $\% 20$ жк 20акварель\&rpt=simage\&rlt_url=https $\% 3 \mathrm{~A} \% 2$ F\%2Fkovrov.city\%2Fuploads\%2Fnews\%2F1_3_19_148_ 120002.jpg\&ogl_url=https\%3A\%2F\%2Fwww.skcontinent.ru\%2Fupload\%2Fimages\%2FAkvareli_hit_ prodazh_klassicheskaya_odn._fs_(Copy).jpg (accessed: 21.08.2021). (In Russian)

Natsional'nyi korpus russkogo iazyka [Russian National Corpus]. URL: http://www.ruscorpora (accessed: 10.09.2021). (In Russian)
Nikolaev, G. A. (2011). Russkoe i slavianskoe iazykoznanie [Russian and Slavic Linguistics]. Pod obshh. red. K. R. Galiullina; Kazan. un-t, Filol. fak. 220 p. Kazan', Kazan. un-t. (In Russian)

Polnotsennaia odnushka s garderobnoi [A Proper One-roomed Flat with a Dressing Room]. URL: https://yandex.ru/images/search?pos $=173 \& \mathrm{p}=5 \&$ img_url $=$ https $\% 3 \mathrm{~A} \% 2 \mathrm{~F} \% 2 \mathrm{Fwww}$. sk-continent.ru\%2Fupload $\%$ 2Fimages\%2FAkvareli_hit_prodazh_klassicheskaya_odn. _fs_(Copy).jpg\&text=однушка\% 20в\% 20зеленодольске \%20жк\%20акварель\&rpt=simage\&rlt_url=http\%3A\%2F \%2Fitd2.mycdn.me\%2Fimage\%3Fid\%3D901508640427 \%26t\%3D20\%26plc\%3DMOBILE\%26tkn\%3D*c_AJHm 3SxjqvoseUqWIkE7NJJQc\&ogl_url=https\%3A\%2F\%2F www.sk-continent.ru\%2Fupload\%2Fimages $\%$

2FAkvareli_hit_prodazh_klassicheskaya_odn._fs_(Copy). jpg (accessed: 13.06.2021). (In Russian)

Russkaia grammatika. T. 1: Fonetika. Fonologija. Udarenie. Intonatsiia. Slovoobrazovanie. Morfologiia (1980) [Russian Grammar. Vol. 1: Phonetics. Phonology. Stress. Intonation. Word Formation. Morphology]. N. Ju. Shvedova (gl. red.). 743 p. Moscow, Nauka. (In Russian)

Sorokina, T. N. (1988). "Sovest'" ili "So+vest'", ["Conscience" or "Con + science"]. Russkii iazyk v shkole. Moscow, "Prosveshhenie”, No 3, pp. 89-91. (In Russian)

Suhachev, N. L. (2019). Znachenie $i$ smysl slova. Lektsii o lingvisticheskom znake [The Sense and Meaning of the Word. Lectures on the Linguistic Sign]. 184 p. St. Petersburg, Nestor-Istoriia. (In Russian)

Tolkovyi slovar' kontsa XX veka. Iazykovye izmeneniia (1998) [Explanatory Dictionary of the Late 20th Century. Language Changes]. Pod. red. G. N. Skliarevskoi. 704 p. St. Petersburg, FOLIO-PRESS. (In Russian)

Toporov, V. N. (2005). Issledovaniia po etimologii $i$ semantike. T. 1: Teoriia $i$ nekotorye chastnye ee prilozheniia [Research on Etymology and Semantics. Vol.1: Theory and Some of Its Particular Applications]. 816 p. Moscow, Iazyki slavianskoi kul'tury. (In Russian)

Uluhanov, I. S. (1977). Slovoobrazovatel'naia semantika $v$ russkom iazyke i principy ee opisaniia [Derivational Semantics in Russian and the Principles of Its Description]. 255 p. Moscow, Nauka. (In Russian)

Ullmann, S. (1973). Semantik. Eine Einführung in die Bedeutungslehre [Semantics. An Introduction to the Theory of Meaning]. 401 p. Frankfurt am Main, S. Fischer Verlag. (In German)

Vinogradov, V. V. (1954). Iazyk hudozhectvennogo proizvedeniia [The Language of Fiction]. Voprosy iazykoznaniia. No. 5, p.10. (In Russian)

Vinokur, G. O. (1959). Zametki po russkomu slovoobrazovaniiu [Notes on Russian Word Formation]. "Izbrannye raboty po russkomu iazyku". 426 p. Moscow. (In Russian)

Zalizniak, Anna i dr. (2012). Konstanty i peremennye russkoi iazykovoi kartiny mira [Constants and Variables of the Russian Language Picture of the World]. 696 p. Moscow, Izdatel'skii dom "IaSK". (In Russian)

Zalizniak, Anna A. (2013). Russkaia semantika v tipologicheskoi perspektive [Russian Semantics in a Тy- 
pological Perspective]. 640 p. Moscow, Iazyki slavianskoi kul'tury. (In Russian)
Zatsepin, A. (2021). Dolia ty moia, dolia-doliushka [This Is My Fate, Dolya-Dolyushka]. URL: https://pesni.guru (accessed: 12.08.2021). (In Russian)

The article was submitted on 12.09.2021 Поступила в редакцию 12.09.2021

\section{Абдулганеева Ирина Игоревна,} кандидат филологических наук, доцент,

Казанский федеральный университет, 420008 , Россия, Казань, Кремлевская, 18. abdulganii@bk.ru

\author{
Abdulganeeva Irina Igorevna \\ Ph.D. in Philology, \\ Associate Professor, \\ Kazan Federal University, \\ 18 Kremlyovskaya Str., \\ Kazan, 420008, Russian Federation. \\ abdulganii@bk.ru
}

